UDC 539.3

\title{
MODIFIED METHOD OF LINES IN THE PROBLEMS OF THERMAL CONDUCTIVITY OF ANNULAR PLATES
}

\author{
Yu.V. Sovych \\ Kyiv National University of Construction and Architecture, \\ Kyiv, Povitroflotskyi ave., 31, Kyiv. 03037
}

DOI: $10.32347 / 2410-2547.2020 .105 .302-309$

The application of the modified method of lines to reduce the dimensionality of the initial system of equations of nonstationary thermal conductivity used to determine the temperature fields of the load-bearing elements is shown in this paper. Reducing the dimensionality of the original equations by one spatial coordinate, in this case by the $\mathrm{z}$ coordinate, is performed using the projection method. Local basic functions are used for this purpose. To ensure the unambiguity of the solutions, the reduced equations are supplemented by initial and boundary conditions.

Keywords: thermal conductivity, dimension reduction, projection method, reduced equations, modified method of lines

Ring plates, the overall dimensions of which have the same degree under thermal influences, have spatial temperature fields. If these effects are axisymmetric relative to the vertical axis of the plate, then such fields are also axisymmetric, i.e. twodimensional in spatial coordinates in a cylindrical coordinate system (Fig. 1). In addition, the temperature field may depend on the time coordinate, i.e. is nonstationary. The initial equation of nonstationary thermal conductivity is considered as the first order system of partial differential equations:

- Fourier's Law:

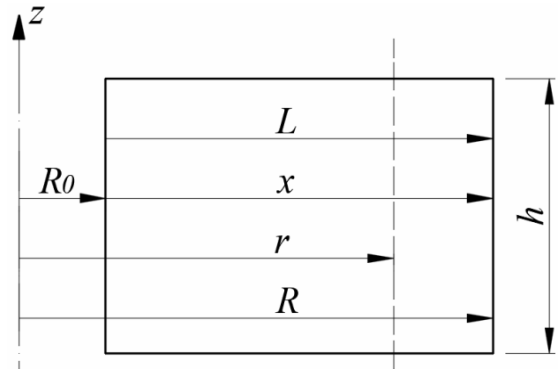

Fig. 1

$$
\begin{aligned}
& q_{r}=-\lambda_{T} \cdot \frac{\partial T}{\partial x}, \\
& q_{z}=-\lambda_{T} \cdot \frac{\partial T}{\partial z}
\end{aligned}
$$

- heat balance equation:

$$
\rho c \frac{\partial T}{\partial t}=-\frac{q_{r}}{x+R_{0}}-\frac{\partial q_{r}}{\partial x}-\frac{\partial q_{z}}{\partial z}+Q_{T},
$$

where $T(x, z, t)$ is the temperature function, $q_{r}(x, z, t), q_{z}(x, z, t)$ are the components of the heat flux vector, $\rho$ is the density of the plate material, $c$ is the specific heat.

C) Sovych Yu.V. 
Since a linear substitution of the independent variable $r=R_{0}+x$ is used here, the relation $\frac{\partial}{\partial r}=\frac{\partial}{\partial x}$ is obtained as a result. This was used in equation (2).

Unknown functions included in the initial equations (1), (2) must satisfy the boundary conditions, which are selected in the most general form as conditions of convective heat transfer between the boundary surfaces of the body and the environment.

In the case when $r=R_{0}$ :

$$
q_{r}(0, z, t)=q_{r, c}^{0}(z, t)-\alpha^{0}\left[T(0, z, t)-\theta_{c}^{0}(z, t)\right],
$$

when $x=L$ :

when $z=h^{-}$:

$$
q_{r}(L, z, t)=q_{r, c}^{L}(z, t)-\alpha^{L}\left[T(L, z, t)-\theta_{c}^{L}(z, t)\right] ;
$$

$$
q_{z, c}^{-}(x, t)-\alpha^{-}\left[T\left(x, h^{-}, t\right)-\theta_{c}^{-}(x, t)\right],
$$

when $z=h^{+}$:

$$
q_{z, c}^{-}\left(x, h^{+}, t\right)=q_{z, c}^{+}(x, t)+\alpha^{+}\left[T\left(x, h^{-}, t\right)-\theta_{c}^{+}(x, t)\right]
$$

Here the symbol "c" indicates the known values of the quantities relating to the external environment; $\theta_{c}$ is the ambient temperature near the corresponding area of the body surface, $\alpha$ is the coefficient of convective heat transfer. It should be noted that when $\alpha=0$ we have a boundary condition of the second kind, when $\alpha \rightarrow \infty$ we have a boundary condition of the first kind. As an initial condition, consider the standard ratio: when $t=0$ :

$$
T(x, z, 0)=T_{0}(x, z),
$$

where $T_{0}(x, z)$ is the initial temperature distribution function at all points of the body.

The form of initial equations accepted in this work provides simplicity of application of dimension reduction of initial system of equations by means of the modified method of lines [6], [7]. According to the mentioned works, the dimension reduction of the initial equations by one spatial coordinate, in this case on $z$, it is assumed by means of the projection method [3] using as basic functions of the system the so-called functions - "caps", which are related to the lines drawn on the definition domain of the problem $z=\left(h_{z}^{+}-h_{z}^{-}\right) /\left(N_{z}-1\right) \cdot i$, where $i=\overline{1, N_{z}}$ taking into account the edge lines $i=1_{z}, i=N_{z}$.

The use of locally concentrated basis functions greatly simplifies the preliminary calculations, but requires significant explanations for the correct application of the modified method of line. The fact is that from the point of view of the vector space theory in which a scalar product is defined, the chosen system of basis functions is not orthogonal. In this case, a technique for using 
oblique bases is developed in tensor algebra. $\mathrm{n}$ addition to the chosen covariant basis, which is considered the main one, it is necessary to consider the contravariant basis, which ensures the correct application of oblique bases. In the modified method of lines, the sequence of dimension reduction and all related mathematical operations are implemented according to standard operations of tensor algebra [4].

Using a scalar multiplication in functional space

$$
(f(z), g(z))=\int_{h_{z}^{-}}^{h_{z}^{+}} f(z), g(z) d z
$$

we obtain:

$$
\left(\frac{\partial T}{\partial x}=-\frac{1}{\lambda_{T}} \cdot q_{r}\right), \varphi_{i}(z) \Rightarrow \frac{\partial T^{i}(x, t)}{\partial x}=-\frac{1}{\lambda_{T}} \cdot q_{r}^{i}(x, t) .
$$

Here it is taken into account that the derivative $\frac{\partial}{\partial x}$ can be moved outside the integral sign, since the integration occurs with respect to variable $z$, and the scalar product of any function and basis function with a superscript is the coefficient of this function with respect to the decomposition in basis functions of the basic basis. That is

$$
\left(f(x, z, t), \varphi^{i}(z)\right)=f^{i}(x, t) .
$$

Here and further on the repeated indices in two-term expressions summation (Einstein summation convention) is used.

$$
\begin{aligned}
& \left(q_{z}=-\lambda_{T} \cdot \frac{\partial T}{\partial z}\right), \varphi^{i}(z) \Rightarrow q_{z}^{i}=-\lambda_{T} \cdot \int_{h_{z}^{-}}^{h_{z}^{+}} \frac{\partial T}{\partial z} \cdot g^{i j} \cdot \varphi_{j}(z) d z= \\
& =-\lambda_{T} \cdot g^{i j} \cdot \int_{h_{z}^{-}}^{h_{z}^{+}} \frac{\partial}{\partial z}\left(T^{\alpha} \cdot \varphi_{\alpha}(z)\right) \cdot \varphi_{j}(z) d z=-\lambda_{T} \cdot g^{i j} \cdot b_{j \alpha} \cdot T^{\alpha}(x, t) ;
\end{aligned}
$$

The tensor operation of lowering indices

$$
\varphi^{i}(z)=g^{i j} \cdot \varphi_{j}(z)
$$

using a twice contravariant metric tensor applied here

$$
g^{i j}=\left(\varphi^{i}(z), \varphi^{j}(z)\right) .
$$

Marked here

$$
b_{j \alpha}=\int_{h_{z}^{-}}^{h_{z}^{+}} \varphi_{j}(z) \cdot \varphi_{\alpha}^{\prime}(z) d z .
$$

Finally we get the second reduced equation:

$$
q_{z}^{i}(x)=-\lambda_{T} \cdot g^{i j} \cdot b_{j \alpha} \cdot T^{\alpha}(x, t) .
$$

When reducing the heat balance equation, a distinction should be made between functions that are twice differentiated with respect to spatial coordinates - $T(x, z)$ and once differentiated - the components of the heat flux 
vector $q_{r}(x, z, t)$ and $q_{z}(x, z, t)$. When calculating integrals in a sequence similar to sequence (9), it is necessary to apply the "softening" of integration [3] using integration by parts:

$$
\begin{aligned}
& \left(\rho c \frac{\partial T}{\partial t}=-\frac{q_{r}}{x+R_{0}}-\frac{\partial q_{r}}{\partial x}-\frac{\partial q_{z}}{\partial z}+Q_{T}\right), \varphi^{i}(z) \Rightarrow \\
& \Rightarrow \rho c \frac{\partial T^{i}}{\partial t}=-\frac{q_{r}^{i}}{x+R_{0}}-\frac{\partial q_{r}^{i}}{\partial x}-\left(\frac{\partial q_{z}}{\partial z}, g^{i j} \cdot \varphi_{j}(z)\right)+Q_{T}^{i} .
\end{aligned}
$$

Here it is necessary to calculate the component separately

$$
\begin{aligned}
& -\left(\frac{\partial q_{z}}{\partial z}, g^{i j} \cdot \varphi_{j}(z)\right)=-g^{i j} \cdot\left(\frac{\partial q_{z}}{\partial z}, \varphi_{j}(z)\right)=-g^{i j} \cdot \int_{h_{z}^{-}}^{h_{z}^{+}} \frac{\partial q_{z}}{\partial z} \cdot \varphi_{j}(z) d z= \\
& =g^{i j} \cdot\left|\begin{array}{l}
u=\varphi_{j}(z) ; d u=\varphi_{j}^{\prime}(z) d z \\
d v=\frac{\partial q_{z}}{\partial z} d z ; v=q_{z}
\end{array}\right|=-g^{i j} \cdot\left[\left.(u \cdot v)\right|_{h_{z}^{-}} ^{h_{z}^{+}}-\int_{h_{z}^{-}}^{h_{z}^{+}} q_{z} \cdot \varphi_{j}^{\prime}(z) d z\right]= \\
& =-g^{i j}\left[\left(q_{z}^{N_{z}} \cdot \delta_{j}^{N_{z}}-q_{z}^{1_{z}} \cdot \delta_{j}^{1_{z}}\right)-\int_{h_{z}^{-}}^{h_{z}^{+}}\left(q_{z}^{\alpha} \cdot \varphi^{\alpha}(z) \cdot \varphi_{j}^{\prime}(z) d z\right)=\right. \\
& =-g^{i N_{z}} \cdot q_{z}^{N_{z}}+g^{i 1_{z}}+g^{i j} \cdot b_{\alpha j} \cdot q_{z}^{\alpha} .
\end{aligned}
$$

Here we are using the operation of index replacement $g^{i j} \cdot \delta_{j}^{1 z}=g^{i 1_{z}}$, $g^{i j} \cdot \delta_{j}^{N_{z}}=g^{i N_{z}}$, because of such interconnections $\left.\varphi(z)\right|^{h_{z}^{+}}=\delta_{i}^{N_{z}},\left.\varphi(z)\right|_{h_{z}^{-}}$this is the value of the functions - "caps" on the edge lines $z=h_{z}^{+}$and $z=h_{z}^{-}$ in accordance, $\delta_{i}^{j}$ - Kronecker symbol.

Einstein summation convention is not possible for fixed indices $1_{z}$ and $N_{z}$. Finally we obtain the reduced equation of heat balance:

$$
\begin{aligned}
& \rho c \frac{\partial T^{i}(x, t)}{\partial t}=-\frac{q_{r}^{i}(x, t)}{x+R_{0}}-\frac{\partial q_{r}^{i}(x, t)}{\partial x}+g^{i j} \cdot b_{\alpha j} \cdot q_{z}^{\alpha}(x, t)-g^{i N_{z}} \cdot q_{z}^{N_{z}}(x, t)+ \\
& +g^{i 1_{z}} \cdot q_{z}^{{ }^{l_{z}}}(x, t)+Q_{T}^{i}(x, t)
\end{aligned}
$$

Equations (7), (13) and (16) form a complete system of reduced solving equations. But for further application of numerical methods for its solution it is more convenient to reduce it to one equation of the second order on spatial coordinates, having excluded from equations of heat balance the components of the heat flux vector, having written down their coordinates in the corresponding kind:

$$
q_{r}^{i}(x, t)=-\lambda_{T} \cdot \frac{\partial T^{i}(x, t)}{\partial x}, \quad q_{z}^{\alpha}(x, t)=-\lambda_{T} \cdot g^{\alpha \beta} \cdot b_{\beta \gamma} \cdot T^{\gamma}(x, t) .
$$

As a result we receive:

$$
\rho c \frac{\partial T^{i}(x, t)}{\partial t}=\lambda_{T}\left[\frac{\partial^{2} T^{i}(x, t)}{\partial x^{2}}+\frac{1}{x+R_{0}} \cdot \frac{\partial T^{i}(x, t)}{\partial x} \cdot g^{i j} \cdot b_{\alpha j} \cdot g^{\alpha \beta} \cdot b_{\beta \gamma} \cdot T^{\gamma}(x, t)\right]+Q_{T}^{i} .
$$


In the case of a stationary thermal process, the initial functions are unknown and, accordingly, the reduced functions do not depend on the time variable, and then the obtained reduced equations are ordinary differential equations that depend on the $\mathrm{x}$-coordinate. In this case, it is more convenient to use the system of equations (7), (3), (16) to calculate the stationary temperature field.

To ensure the unambiguity of the solutions, the reduced equations must be supplemented by initial and boundary conditions, which we obtain from the initial conditions (5) by scalarly multiplying it by the basic functions of the reciprocal basis $\varphi^{i}(z)$. Since the scalar product here is integration with respect to $z$, the result is:

when $t=0$ :

$$
T^{i}(x, z, 0)=T^{i}(x, 0) .
$$

Boundary conditions for reduced equations are also obtained from the initial boundary conditions. Since the initial equations are chosen as a system of first-order differential equations in first-order partial derivatives, the initial boundary conditions have the form of algebraic equations. In this regard, the reduced boundary conditions formally look like the initial ones, if the unknown functions included in them are replaced by the coefficients of these functions, ie:

$$
\begin{aligned}
T(x, z, t) & \rightarrow T^{i}(x, t), \\
q(x, z, t) & \rightarrow q^{i}(x, y) .
\end{aligned}
$$

We get:

when $x=0$ :

$$
q_{r}^{i}(0, t)=q_{r, c}^{0, i}-\alpha^{0} \cdot\left[T^{i}(0, t)-\theta_{c}^{0, i}(t)\right]
$$

when $x=L$ :

$$
q_{r}^{i}(L, t)=q_{r, c}^{L, i}-\alpha^{L} \cdot\left[T^{i}(L, t)-\theta_{c}^{L, i}(t)\right] .
$$

Reduced equations in the obtained form take into account only the threedimensional effects $Q_{T}(x, z, t)$. But, as a rule, this is not enough. Most real thermal effects occur due to the body's contact with the environment through boundary surfaces. In this calculation model, the contact with the external environment occurs through the end surfaces $x=0$ and $x=L$ and is taken into account by boundary conditions (3) and, accordingly, reduced (20), (21).

To take into account the thermal effects from the external environment through the boundary planes $z=h_{z}^{-}, z=h_{z}^{+}$it is necessary to include conditions (4) in the reduced equations of heat balance, excluding from these equations the components $q_{z}^{1 z}$ та $q_{z}^{N z}$ by means of relations (4). Thus, all possible thermal effects on the calculated object are taken into account: 


$$
\begin{aligned}
& \rho c \frac{\partial T(x, t)}{\partial t}=\lambda_{T}\left[\frac{\partial^{2} T^{i}(x, t)}{\partial x^{2}}+\frac{1}{x+R_{0}} \cdot \frac{\partial T(x, t)}{\partial x}-g^{i N z} \cdot \alpha_{T}^{+} \cdot T^{N z}(x, t)-\right. \\
& \left.-g^{i 1 z} \cdot \alpha_{T}^{-} \cdot T^{1 z}(x, t)+g^{i j} \cdot b_{\alpha j} \cdot g^{\alpha \beta} \cdot b_{\beta \gamma} \cdot T^{\gamma}(x, t)\right]+\bar{Q}_{T}^{0},
\end{aligned}
$$

where

$$
\bar{Q}_{T}^{i}=Q_{T}^{i}-g^{i N z} \cdot\left(q_{z, c}^{+}(x, t)-\alpha^{+} \cdot \theta_{c}^{+}(x, t)\right)+\left(q_{z}^{i l z} \cdot(x, t)+\alpha_{T}^{-} \cdot \theta_{c}^{-}(x, t)\right) .
$$

Conclusions. In this work, a modified method of straight lines is used to reduce the dimension of the initial system of equations of nonstationary thermal conductivity recorded in a cylindrical coordinate system. The most successful form of writing the original equations was found, which ensures ease of application of dimensionality reduction of the initial system of equations using a modified method of lines. The influence of the environment was taken into account. Initial and boundary conditions were written for this purpose. Thus, the reduced equations, boundary and initial conditions were obtained. All this makes it possible to further investigate the temperature fields of the load-bearing elements in their calculation of thermal effects.

\section{REFERENCES}

1. Kovalenko A. D. Vvedenie v termouprugost' (Introduction to thermoelasticity)/ A. D. Kovalenko. - Kiev: Naukova dumka, 1965. - 204 s.

2. Karslou G. Teploprovodnost' tverdyh tel (Thermal conductivity of solids)/ G. Karslou, D. Eger. - Moskva: Nauka, 1964. - 488 s.

3. Marchuk G. I. Vvedenie v proekcionno-setochnye metody (Introduction to projection-grid methods)/ G. I. Marchuk, V. I. Agoshkov. - Moskva: Nauka, 1981. - 416 s.

4. Modifikovanij metod pryamih, algoritm jogo zastosuvannya, mozhlivosti ta perspektivi (Modified method of direct, algorithm of its application, possibilities and prospects)/ [ $V . K$. Chibiryakov, A. M. Stankevich, O. P. Koshevij ta in.]. // Mistobuduvannya ta teritorial'ne planuvannya. - 2019. - №70. - S. 595-616.

5. Chibiryakov V.K. Diskretno-kontinual'na model' dlya rozrahunku tovstih plastin na dinamichni vplivi (Discrete-continuous model for calculating thick plates on dynamic effects) / V. K. Chibiryakov, A. M. Stankevich, D. V. Levkivs'kij. // Mistobuduvannya ta teritorial'ne planuvannya. - 2014. - №51. - S. 678-687.

6. Chibiryakov $V$. K. Pro odin algoritm rozv'yazannya pochatkovo-granichnih zadach dlya rivnyannya nestacionarnoï teploprovidnosti (About one algorithm for solving initialboundary value problems for the equation of nonstationary thermal conductivity) $/ V . K$. Chibiryakov, A. M. Stankevich, V. F. Mel'nichuk. // Opir materialiv i teoriya sporud. - 2015. - №95. - S. 90-95.

7. Application of generalized "method of lines", for solving problems of thermoelasticity of thick plates. / V.Chybiryakov, A. Stankevich, D. Levkivskiy, V. Melnychuk. // "Motrol". 2014. - №8. - C. 11-20. 


\section{Сович Ю.В.}

\section{МОДИФІКОВАНИЙ МЕТОД ПРЯМИХ В ЗАДАЧАХ ТЕПЛОПРОВІДНОСТІ КІЛЬЦЕВИХ ПЛАСТИН}

У даній роботі пропонується розв'язувати початково-граничну задачу теплопровідності за допомогою чисельно-аналітичного методу - модифікованого методу прямих. Вихідні рівняння теплопровідності визначені в циліндричній системі координат розглядаються в просторовій постановці, що значно їх ускладнює. В якості об’єкта, на якому вони визначені, розглядається кільцева пластина, габаритні розміри якої, співрозмірні. В задачах розрахунку несучих елементів на теплові впливі першим етапом $\epsilon$ визначення температурних полів, особливо, якщо габаритні розміри конструкцій співрозмірні. До таких елементів відносяться нетонкі кільцеві пластини. Граничні умови розглядаються теж у загальному вигляді - це умови конвективного теплообміну, які за допомогою граничного переходу перетворюються в граничні умови першого та другого типів. У даній роботі показано застосування модифікованого методу прямих для зниження вимірності вихідної системи рівнянь нестаціонарної теплопровідності, що застосовуються для визначення температурних полів несучих елементів.

Застосування модифікованого методу прямих передбачає розв'язувати вказані початково-граничні задачі в два етапи. На першому етапі по одній просторовій координаті z знижується вимірність вихідних рівнянь. Для зниження вимірності використовується проекційний метод Бубнова-Гальоркіна-Петрова. В якості базисних функцій приймаються так звані функції-кришки, які пов'язані з прямими, що нанесені на область визначення даної задачі. Проекційний метод також використовується для зниження вимірності початкових та граничних умов, що дозволяє поставити редуковану початково-граничну задачу, яку зручно розв'язувати чисельним скінченно-різницевим методом, використовуючи явні або неявні різницеві схеми. Знайдено найоптимальнішу форму написання вихідних рівнянь, що забезпечує легкість зниження вимірності вихідної системи рівнянь за допомогою модифікованого методу прямих. При розрахунку було враховано вплив навколишнього середовища. В результаті, було отримано редуковані рівняння, граничні та початкові умови. Редукована задача має вигляд, зручний для застосування до її розв'язання сучасними чисельними методами.

Ключові слова: теплопровідність, зниження вимірності, проекційний метод, редуковані рівняння, модифікований метод прямих.

\section{Sovych Yu.V.}

\section{MODIFIED METHOD OF LINES IN THE PROBLEMS OF THERMAL CONDUCTIVITY OF ANNULAR PLATES}

In this paper, to solve the initial boundary value problem of thermal conductivity using a numerical-analytical method - a modified method of lines is proposed. The initial equations of thermal conductivity defined in the cylindrical coordinate system are considered in the spatial formulation, which greatly complicates them. As an object on which they are defined, an annular plate is considered, the overall dimensions of which are commensurate. In the problems of calculating of thermal effects in load-bearing elements the first step is to determine the temperature fields, especially if the overall dimensions of the structures are proportional. Such elements include non-thin annular plates. The boundary conditions are considered in a general form too - these are the conditions for convective heat transfer, which using the passage to the limit, turn into boundary conditions of the first and second types. The application of the modified method of lines to reduce the dimensionality of the initial system of equations of nonstationary thermal conductivity used to determine the temperature fields of the load-bearing elements is shown in this paper.

The application of the modified method of lines involves solving these initial boundary value problems in two stages. At the first stage, the dimensionality of the initial equations with respect to variable $\mathrm{z}$ is reduced. The Bubnov-Galerkin-Petrov projection method is used to reduce the dimensionality. The so-called functions-"caps" are accepted as basic functions, which are related to the lines plotted on the definition domain of the problem. The projection method is also used to reduce the dimension of the initial and boundary conditions, that allows to formulate a reduced initial-limit problem, which is convenient to solve using the numerical finite-difference method, 
using explicit or implicit difference schemes. The most successful form of writing the original equations was found, which ensures ease of application of dimensionality reduction of the initial system of equations using a modified method of lines. The calculation took into account the impact of the environment. Reduced equations, boundary and initial conditions are obtained. As a result, the reduced problem has a form convenient to its solution by modern numerical methods.

Keywords: thermal conductivity, dimension reduction, projection method, reduced equations, modified method of lines.

\section{УДК 539.3}

Сович Ю.В. Модифікований метод прямих в задачах теплопровідності кільцевих пластин // Опір матеріалів і теорія споруд: наук.-тех. збірн. - К.: КНУБА, 2020. - Вип.105. С. 302-309. - Англ.

У даній роботі показано застосування модифікованого методу прямих для зниження вимірності вихідної системи рівнянь нестаціонарної теплопровідності, щцо застосовуються для визначення температурних полів несучих елементів. Зниження вимірності вихідних рівнянь по одній просторовій координаті, в даному випадку саме по z виконується за допомогою проекційного методу. Для цього використовуються локальні базисні функиії. Для забезпечення однозначності розв'язків редуковані рівняння доповнються початковими та граничними умовами.

Іл. 1. Бібліогр. 7 назв.

\section{UDC 539.3}

Sovych Yu.V. Modified method of direct in problems of thermal conductivity of annular plates // Strength of Materials and Theory of Structures: Scientific-and-technical collected articles. - K.: KNUBA, 2020. - Issue 105. - P. 302-309.

The application of the modified method of lines to reduce the dimensionality of the initial system of equations of nonstationary thermal conductivity used to determine the temperature fields of the load-bearing elements is shown in this paper. Reducing the dimensionality of the original equations by one spatial coordinate, in this case by the z coordinate, is performed using the projection method. Local basic functions are used for this purpose. To ensure the uniqueness of the solutions, the reduced equations are supplemented by initial and boundary conditions.

Fig. 1. Ref. 7.

Автор (науковий ступінь, вчене звання, посада): аспірант кафедри опору матеріалів КНУБА СОВИЧ Юлія Вікторівна

Адреса робоча: 03680 Украӥна, м. Київ, Повітрофлотський проспект 31, КНУБА, кафедра опору матеріалів, Сович Юлія Вікторівна.

Мобільний тел.: +38(098)981-57-31

E-mail: yuliiasov@bigmir.net

ORCID ID: http://orcid.org/0000-0002-5114-6363 